\title{
The tobacco Ntann12 gene, encoding an annexin, is induced upon Rhodoccocus fascians infection and during leafy gall development
}

\author{
OLIVIER VANDEPUTTE ${ }^{1}$, YVES OUKOUOMI LOWE', SYLVIA BURSSENS², DAMIEN VAN \\ RAEMDONCK ${ }^{1}$, DAVID HUTIN ${ }^{1}$, DELPHINE BONIVER ${ }^{1}$, DANNY GEELEN², MONDHER EL JAZIRI ${ }^{1}$ \\ AND MARIE BAUCHER ${ }^{1 *}$

\begin{abstract}
${ }^{1}$ Laboratoire de Biotechnologie Végétale, Université Libre de Bruxelles, Rue Adrienne Bolland 8, B-6041 Gosselies, Belgium
${ }^{2}$ The Institute of Plant Biotechnology for Developing Countries, Department of Molecular Genetics, Ghent University, K.L. Ledeganckstraat 35, B-9000 Gent, Belgium

${ }^{3}$ Department of Plant Systems Biology, Flanders Interuniversity Institute for Biotechnology, Ghent University, Technologie Park 927, B-9052 Gent, Belgium
\end{abstract}

\section{SUMMARY}

Annexins are calcium-binding proteins that have been associated in plants with different biological processes such as responses to abiotic stress and early nodulation stages. Until now, the implication of annexins during plant-pathogen interactions has not been reported. Here, a novel plant annexin gene induced in tobacco BY-2 cell suspension cultures infected with the phytopathogenic bacterium Rhodococcus fascians (strain D188) has been identified. Expression of this gene, called Ntann12, is also induced, but to a lower extent, by a strain (D188-5) that is unable to induce leafy gall formation. This gene was also induced in BY-2 cells infected with Pseudomonas syringae but not in cells infected with Agrobacterium tumefaciens or Escherichia coli. Ntann12 expression was also found to be stimulated by abiotic stress, including $\mathrm{NaCl}$ and abscissic acid, confirming a putative role in stress signal transduction pathways. In addition, promoter-GUS analyses using homozygous transgenic tobacco seedlings showed that the developmentally controlled expression of Ntann 12 is altered upon R. fascians infection. Finally, up-regulation of Ntann12 during leafy gall ontogenesis was confirmed by RT-qPCR. Discussion is focused on the potential role of Ntann12 in biotic and abiotic stress responses and in plant development, both processes that may involve $\mathrm{Ca}^{2+}$-dependent signalling.

\section{INTRODUCTION}

The phytopathogenic Gram-positive bacterium Rhodococcus fascians infects a wide range of monocotyledonous and dicotyledonous plants, causing several types of malformations (Goethals et al., 2001). The most severe symptom is the leafy gall, a particular

*Correspondence: Tel.: +32 26509579; Fax: +32 26509578;

E-mail: mbaucher@ulb.ac.be hyperplasia comprising small leaves and numerous buds that are inhibited in their further outgrowth (Vereecke et al., 2000). Phenotypic characteristics of the leafy gall are reminiscent of cytokinins and auxin action and $R$. fascians has indeed been shown to synthesize several cytokinins (Eason et al., 1996) and the auxin indole-3-acetic acid (IAA) (Vandeputte et al., 2005). The pathogenicity of $R$. fascians has been linked to the presence of a linear plasmid, pFiD188, which carries several virulence genes including an isopentenyl transferase (ipt) homologue that is indispensable for leafy gall formation (Crespi et al., 1992). Indeed, mutation in this ipt homologue and plasmid-free strains, such as the avirulent strain D188-5, are unable to induce leafy gall development (Crespi et al., 1992, 1994).

Plant responses upon $R$. fascians infection involve noticeable phenolic pattern alterations and gene expression changes. For instance, the coumarin derivative 7-methyl esculin has been identified in leafy gall but was not detected in non-infected plant tissues (Vereecke et al., 1997). Changes in the concentration of other phenolics, such as caffeic acid and a cinnamoyl analogue, have also been reported (Vereecke et al., 1997) but the impact of these changes on leafy gall development remains unclear. Regarding gene expression, several studies have reported induced or repressed plant genes during the plant- $R$. fascians interaction. Several cell cycle marker genes, such as $C y c B 1 ; 1$ and $C y C D 3 ; 2$, have been shown to be induced following infection of tobacco and Arabidopsis plants (Vereecke et al., 2000; de 0. Manes et al., 2001). A recent survey of differential gene expression in tobacco axils led to the identification of four genes that were up-regulated following infection with $R$. fascians (Simón-Mateo et al., 2006). Among these, a gibberellin 2-oxidase homologue and an Arabidopsis CYP707A family cytochrome P450 monooxygenase homologue have been identified and were suggested to play a role in gibberellin and abscissic acid (ABA) metabolism, respectively (Simón-Mateo et al., 2006). In another study focusing on the late stages of the interaction in plants, it was shown that genes encoding a chitinase, a $\beta$-1,3-glucanase and a 
pathogenesis-related protein homologous to NtPRp27 were upregulated in leafy galls induced on Atropa belladonna (Nouar et al., 2003). By contrast, a multicystatin-, a miraculin- and a methallothionein-like gene were down-regulated in symptomatic tissues. Because their expression resumed after the elimination of the bacteria from infected tissues, a possible role for these latter genes in shoot development was proposed (Nouar et al., 2003).

At present, no molecular clue regarding the recognition and/ or signalling processes involved during the $R$. fascians-plant interaction has been reported. Studying these processes is hampered by the difficulty in localizing plant cells responding to $R$. fascians and by the unpredictable nature of leafy gall emergence (Simón-Mateo et al., 2006). In that context, the use of a cell suspension model provides a suitable alternative to investigate molecular processes occurring during the early crosstalks between plants and $R$. fascians. Indeed, a more homogeneous plant cell response can be obtained due to the increased number of plant cells that are in contact with the bacteria in comparison with plants infected at localized sites where reacting cells are surrounded by numerous non-infected cells. Therefore, gene expression in non-infected and in $R$. fascians-infected BY-2 tobacco cell suspension cultures was compared using differential display. This transcript profiling resulted in the identification of Ntann12, a gene coding for a novel putative annexin in tobacco. Annexins are viewed as potential links between $\mathrm{Ca}^{2+}$ as an intracellular signal and the regulation of membrane functions (Gerke et al., 2005). In plants, annexins have been implied in different biological processes, including exocytosis/Golgi-mediated vesicle secretion (Carroll et al., 1998; Clark et al., 1992, 2005; Okamoto et al., 2004), responses to abiotic stress (Cantero et al., 2006; Gidrol et al., 1996; Kovács et al., 1998; Kush and Sabapathy, 2001; Lee et al., 2004) and early stages of nodulation in Medicago truncatula upon interaction with the symbiotic bacterium Rhizobium meliloti (de Carvalho-Niebel et al., 1998, 2002; Manthey et al., 2004), but have not been associated with plant-phytopathogen interactions. In this study, we focus on the analysis of Ntann12 expression in BY-2 cells grown under biotic and abiotic stress conditions, and in tobacco plants during seedling development upon infection of tobacco seedlings with $R$. fascians and during leafy gall ontogenesis.

\section{RESULTS}

\section{Identification of Ntann12, an annexin gene induced in BY-2 cell suspensions following $R$. fascians infection}

Gene expression profiles of non-infected and $R$. fascians strain D188 infected BY-2 cell suspensions were compared using differential display. Among the cDNA fragments that showed a differential accumulation following BY-2 cell infection, we focused on one of them for which the expression was up-regulated after

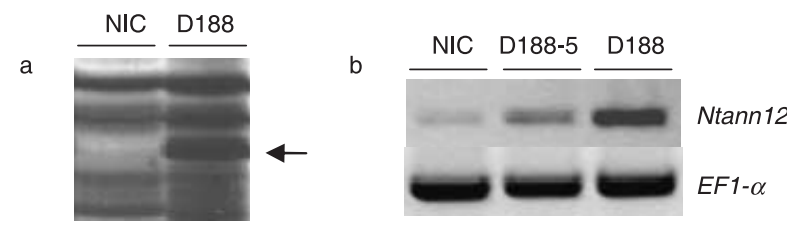

Fig. 1 Ntann12 gene expression analysis in tobacco BY-2 cells co-cultured for 2 days with $R$. fascians. (a) Detail of a differential display gel showing the CDNA fragment (arrow) corresponding to the Ntann 12 gene that is upregulated following infection by $R$. fascians. (b) RT-PCR analysis of Ntann 12 expression in BY-2 cells. NIC, non-infected cells; D188, cells infected by the virulent $R$. fascians strain D188; D188-5, cells infected by the avirulent $R$. fascians strain D188-5. The EF1- $\alpha$ gene was used as a loading control.

2 days of co-culture with the bacteria (Fig. 1a). This result was confirmed in an independent differential display experiment (data not shown). After cloning and sequencing, a BLASTX analysis revealed that the 346-bp cDNA fragment was similar to the 3' end of plant annexins. Following RACE PCR, a 1169-bp cDNA, including a 45-bp 5' untranslated region (UTR) and a 173 bp 3' UTR, was recovered. The 951-bp coding sequence of Ntann12 is predicted to encode a 317-amino-acid polypeptide with a calculated molecular weight of $36 \mathrm{kDa}$ and an isoelectric point of 6.6. Figure 2 shows the alignment of the amino acid sequence of Ntann12 (AAX78199) with the four most similar predicted proteins. Sequence comparison revealed the occurrence in the predicted Ntann12 protein of the four conserved repeats of plant annexins (reviewed by Hofmann, 2004; Moss and Morgan, 2004). Repeat I contains the characteristic type II motif for binding $\mathrm{Ca}^{2+}$ with sequence GXGT(38)D/E and repeat IV is characterized by the conservation of GT nucleotides, as has been reported for other plant annexins (Delmer and Potikha, 1997; Hofmann, 2004).

\section{Ntann12 gene response is not specific to $R$. fascians}

To examine whether the induction of Ntann12 expression was associated with the virulence of the bacterium, RT-PCR analysis was carried out with CDNA prepared from BY-2 cells infected by either the $R$. fascians avirulent strain D188-5 or the virulent strain D188 using primers designed to amplify the entire coding sequence. As shown in Fig. 1b, after 2 days of co-culture, Ntann12 was expressed slightly in non-infected cells and its expression was induced by both bacteria albeit to a lower extent for the avirulent strain D188-5.

In order to determine whether the induction of Ntann12 expression was specific to $R$. fascians, BY-2 cells were infected with $R$. fascians, Pseudomonas syringae pv. tabaci, Agrobacterium tumefaciens or Escherichia coli. As shown in Fig. 3, RT-PCR analysis revealed that Ntann12 expression is clearly induced after 


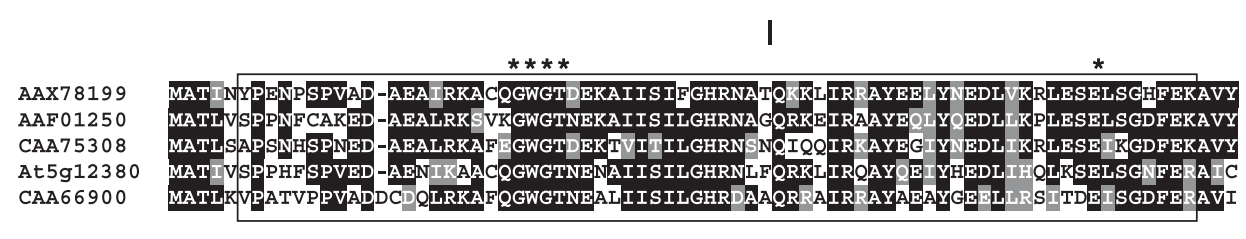

II

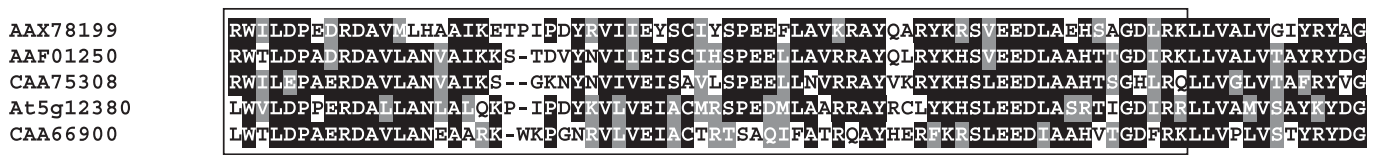

III

AAX78199

AAF 01250

CAA75308

At 5 g 12380

CAA66900

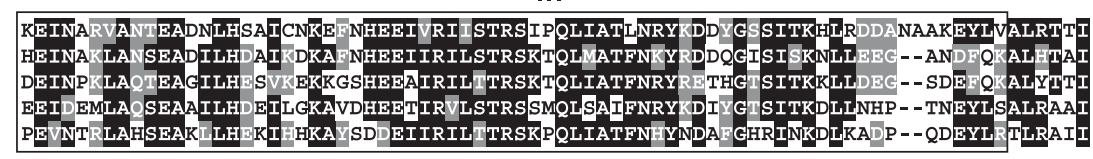

AAX78199
AAF01250
CAA75308
At5g12380
CAA66900

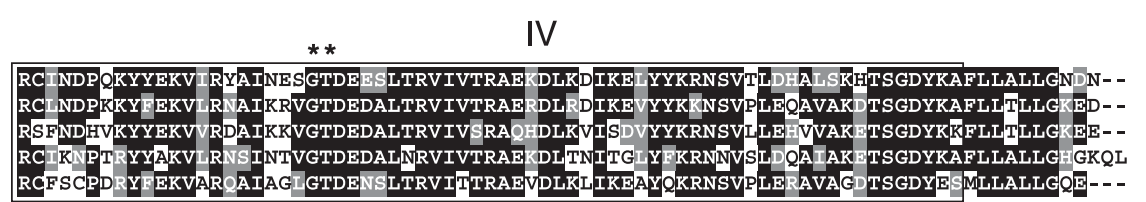

Fig. 2 Comparison of predicted amino acid sequence of Ntann12 (AAX78199) with those of Fragaria $\times$ ananassa (AAF01250), Medicago truncatula Mtann1 (CAA75308), Arabidopsis thaliana AnnAt8 (At5g12380) and Zea mays p33 (CAA66900). Asterisks indicate conserved amino acids for type II Ca²+ binding site GXGT(38)D/E (reviewed by Hofmann, 2004). Identical residues are shaded in black and similar residues are shaded in grey. I-IV indicate the four conserved repeats of annexins (reviewed by Moss and Morgan, 2004). The alignment was made by the CLUSTAL W program and page set-up by the BOXSHADE program.

2 days in cells co-cultured with $R$. fascians and $P$. syringae. Ntann12 expression was not altered in BY-2 cells co-cultured with A. tumefaciens or E. coli. These data indicate that the Ntann12 gene response is not totally associated with $R$. fascians plasmidderived factors and that its expression can be induced by other pathogenic bacteria.

\section{Ntann 12 is induced by abiotic stress}

Ntann12 expression was examined in response to abiotic stress conditions such as $\mathrm{NaCl}, \mathrm{ABA}$ and $\mathrm{H}_{2} \mathrm{O}_{2}$. As shown in Fig. 4, RT$\mathrm{PCR}$ analysis revealed that Ntann12 expression is induced after $8 \mathrm{~h}$ upon $\mathrm{NaCl}$ treatment and after $24 \mathrm{~h}$ upon $\mathrm{ABA}$ treatment, whereas it seems to be unaffected by $\mathrm{H}_{2} \mathrm{O}_{2}$ treatment within $24 \mathrm{~h}$. These data suggest that osmotic factors induce Ntann12 expression but not oxidative stress.

\section{Ntann12 is localized in the cytoplasm of BY-2 cells}

The Ntann12 open reading frame was fused either upstream, downstream or both to the EGFP coding sequence, and the resulting constructs were introduced into BY-2 suspension cells. EGFPfluorescence detection was performed with stably transformed BY-2 cell cultures. As shown in Fig. 5, in interphase cells, fluorescence was localized in the cytoplasm and excluded from the nucleus. The localization pattern was similar for the three different Ntann12EGFP fusion constructs tested. The cytoplasmic localization of Ntann12-EGFP is in agreement with the subcellular localization of other plant annexins that also reside in the cytosol and cell periphery (Breton et al., 2000; Clark et al., 2000; Thonat et al., 1997).

\section{Ntann 12 expression analysis in tobacco plants and in response to $\boldsymbol{R}$. fascians infection}

To monitor tissue and cell expression of Ntann12 during development, a 542-bp DNA segment upstream of the ATG of the Ntann12 gene was amplified by PCR and was fused to a GUS reporter gene. pNtann12-GUS homozygous transgenic tobacco plants were generated and several of these plants were analysed during seedling development. As shown in Fig. 6, GUS activity was detected at the hypocotyl-root junction 3 and 4 days after sowing (Fig. 6a,b). Ten days post-germination, GUS activity was detected locally in the root system but not in the aerial parts of the seedlings (Fig. 6c). Ntann12 expression increased gradually with plant age and was detected in almost all organs 24 days post-germination (Fig. $6 \mathrm{~d}$ ). This pattern is similar to those observed for two Arabidopsis annexin genes (Annat1 and Annat2) 


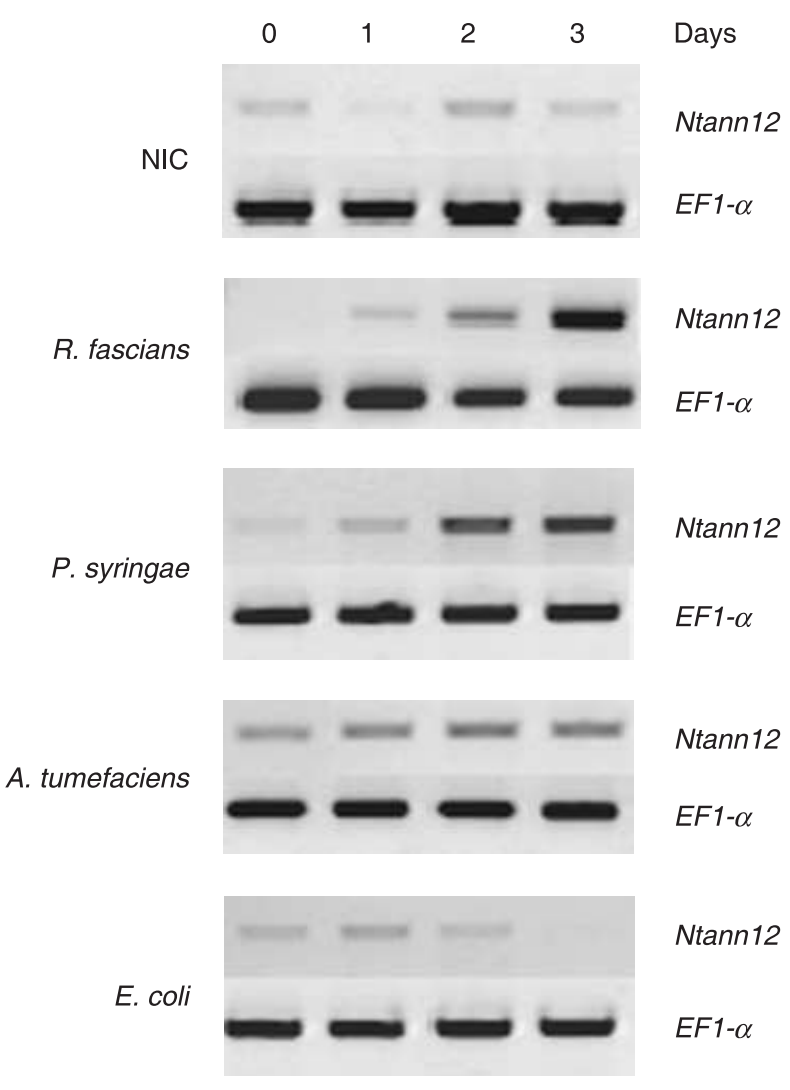

Fig. 3 Effects of biotic stresses on Ntann12 expression. RT-PCR analysis of Ntann 12 gene expression following infection of BY-2 cells by different bacteria. The EF1- $\alpha$ gene was used as a loading control.

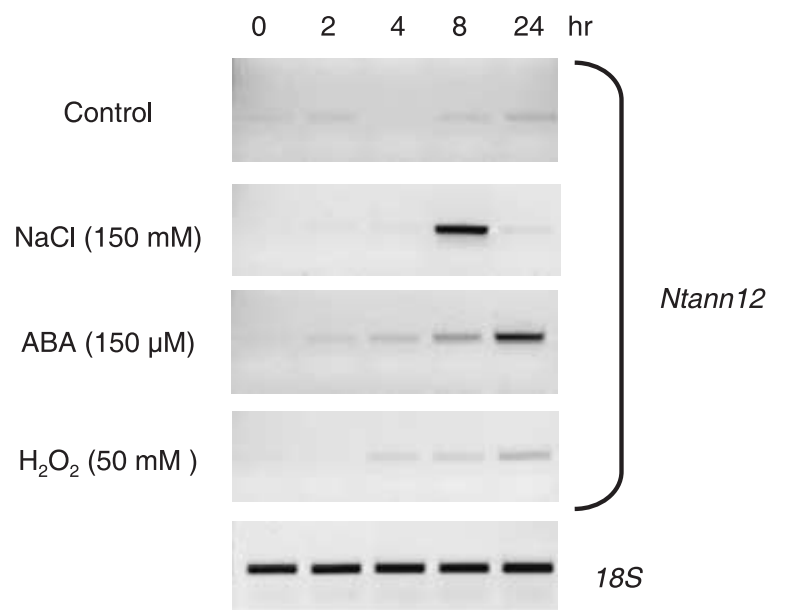

Fig. 4 RT-PCR analysis of Ntann12 expression upon abiotic stresses in BY-2 cells. The 185 gene was used as loading control.

by both in situ RNA localization (Clark et al., 2001) and immunolocalization (Clark et al., 2005).

In order to verify that the isolated promoter was responsive to R. fascians, 11-day-old pNtann12-GUS transgenic plants cultivated
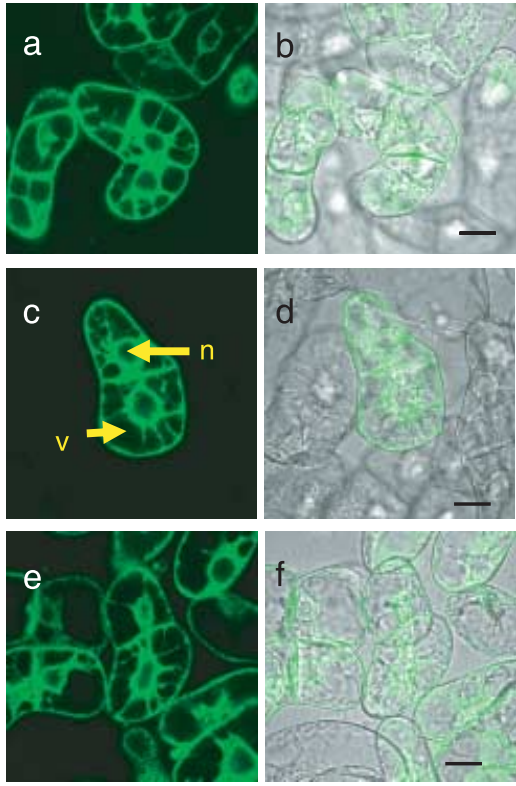

Fig. 5 Intracellular localization of Ntann12 fused to EGFP protein in tobacco BY-2 cells. $(a, b)$ BY2-cells transformed with EGFP-Ntann12. (c,d) BY2-cells transformed with Ntann12-EGFP. (e,f) BY2-cells transformed with EGFP-Ntann12-EGFP. Images were taken by confocal microscopy $(a, c$ and e) dark-field and ( $b, d$ and $f$ ) differential interference contrast. $n$, nucleus; v, vacuole. Scale bar $=100 \mu \mathrm{m}$.

in liquid medium were inoculated with $R$. fascians. GUS staining was applied 7 days post-infection. As shown in Fig. 7, a GUS staining specific to infected plants was detected on the surface of leaves, as revealed by the localized blue spots (Fig. $7 \mathrm{~b}, \mathrm{~d}, \mathrm{f}$ ) that were not observed in non-infected transgenic plants (Fig. 7a,c,e). A closer observation of the blue-stained regions indicated that the Ntann12 promoter response to $R$. fascians infection was pronounced in structures that could be associated with emerging adventitious meristems (Fig. 7f).

\section{Ntann12 expression analysis during the leafy gall ontogenesis}

Expression of Ntann12 was evaluated by RT-qPCR at different developmental stages of leafy galls induced on tobacco plants following spot-inoculation of buds with $R$. fascians D188. Changes in Ntann12 expression were also investigated in plants spot-inoculated with the avirulent $R$. fascians strain D188-5. Non-infected tobacco plants (i.e. spot-inoculated with YEB medium) were used as reference. As shown in Fig. 8, a significant increase in Ntann12 expression occurred after 5 days following bud infection with strain D188. Similarly to the observations made for BY-2 cells (Fig. 1b), Ntann12 expression was higher in D188-infected tissues than in those infected by D188-5, especially 7 days post-infection (Fig. 8). 
Fig. 6 Histochemical analysis of GUS activity during the development of tobacco seedlings transformed with the pNtann12-GUS construct. (a) 3 days post sowing. (b) 4 days post sowingat these stages, GUS activity was detected at the hypocotyl-root junction. (c) 10 days post sowing - GUS activity was detected in parts of the root system. (d) 24 days post sowing. Scale bar $=1 \mathrm{~mm}$.

Fig. 7 Ntann 12 promoter response to $R$. fascians infection of tobacco plants. Eleven-day-old pNtann12-GUS transgenic plants were inoculated with $R$. fascians in liquid medium. GUS staining was made 7 days post-infection. (a) Non-infected transgenic lines. (b) Transgenic plant infected with R. fascians D188. (c,e) Detail of $(a)$. $(d, f)$ Detail of (b). Scale bars $=1 \mathrm{~mm}(\mathrm{a}-\mathrm{d}), 0.2 \mathrm{~mm}(\mathrm{e})$ and $0.1 \mathrm{~mm}(\mathrm{f})$.
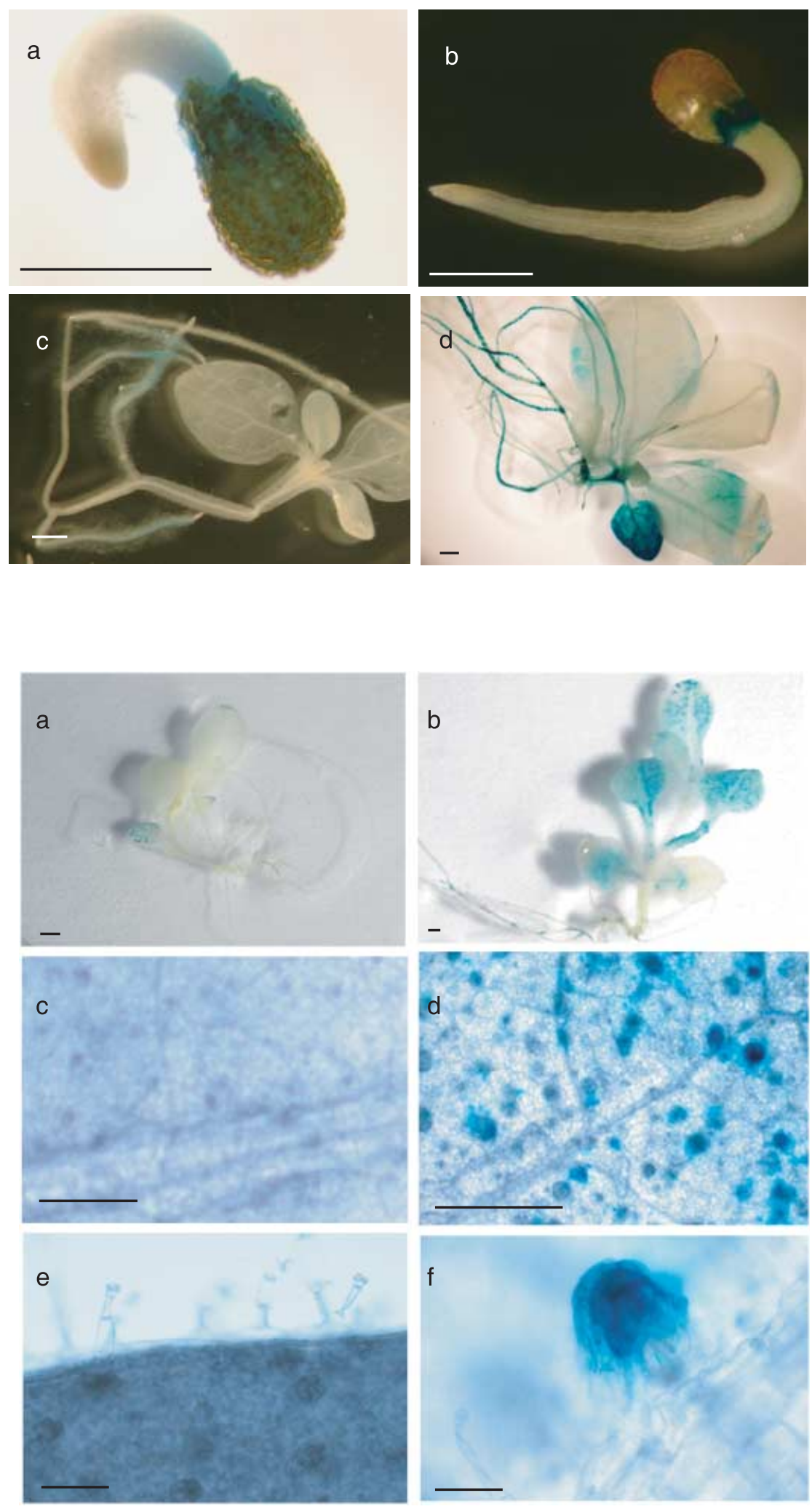


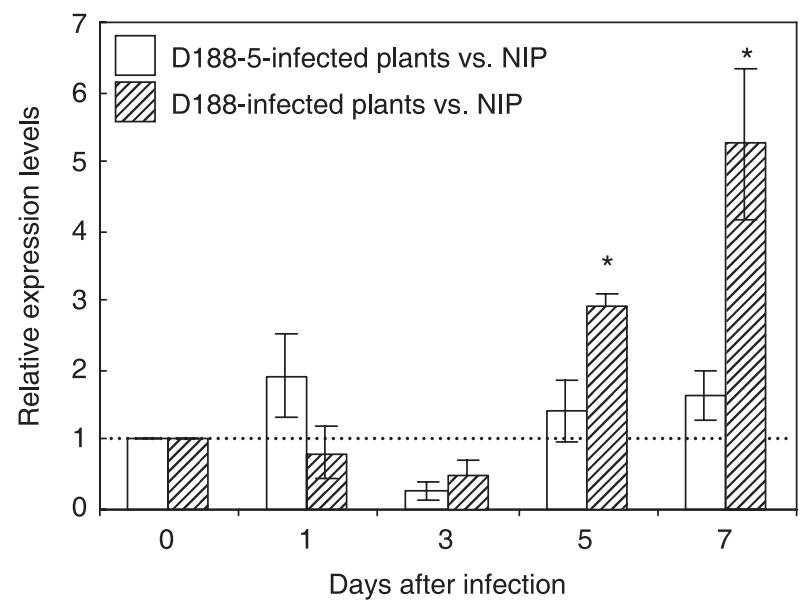

Fig. 8 RT-qPCR analysis of Ntann12 expression during leafy gall ontogenesis. Four-week-old tobacco plants were either mock-infected, spot-inoculated with $R$. fascians strain D188-5 or with $R$. fascians strain D188. EF1- $\alpha$ was used as a template loading control. Relative expression levels are presented as ratios of expression in D188-5-infected plants vs. non-infected plants (NIP) (white bars) and in D188-infected plants vs. NIP (hatched bars). Bars indicate SE $(n=3)$. Asterisks indicate time points for which differences in expression were statistically significant $(P \leq 0.01)$.

\section{DISCUSSION}

This work reports on the identification of a novel tobacco gene induced upon infection by the phytopathogenic actinomycete R. fascians (strain D188) (Fig. 1). This gene has been designated Ntann12 and encodes a putative protein homologous to annexins (Fig. 2), a family of calcium- and phospholipid-binding proteins (Gerke et al., 2005). We have shown that induction of Ntann12 is not specific to $R$. fascians as infection of tobacco BY-2 cells with $P$. syringae pv. tabaci, a virulent pathogen causing chlorotic lesions on tobacco leaves (Anzai et al., 1989), also led to an overexpression of Ntann12 (Fig. 3). Additionally, Ntann12 induction is probably restricted to infection with a certain range of bacteria given that $E$. coli did not trigger the expression of Ntann12 in BY-2 cells. Similarly, co-culture of BY-2 cells with $A$. tumefaciens did not result in an increased accumulation of Ntann12 transcript. This observation is in accordance with a recent study related to the response of Arabidopsis thaliana transcriptome to A. tumefaciens infection that did not highlight an increase in annexin gene expression (Ditt et al., 2006).

Expression of plant annexin genes in response to nonpathogenic bacteria has already been reported. Mtann1 and Mtann2 have been shown to be associated with symbiotic interactions, in Rhizobium inoculated roots and in nodules of M. truncatula (de Carvalho-Niebel et al., 1998, 2002; Manthey et al., 2004). Mtann 1 has been proposed to be involved in the early stages of Nod factor signalling and in the cell cycle activation of cortical cells (de Carvalho-Niebel et al., 1998, 2002). Mtann2 was also found to be expressed in arbuscule-containing cells of mycorrhizal roots, and a role of the protein encoded by this gene in the membrane traffic was hypothesized (Manthey et al., 2004). Whether Ntann 12 could play similar roles during the $R$. fasciansplant interaction remains to be determined.

We have observed that Ntann12 was induced by the avirulent strain D188-5, although this induction was lower in infected BY-2 cells (Fig. 1b) or tobacco plants (Fig. 8) as compared with the induction by the virulent strain D188. This lower induction can result from a difference in plant infection efficiency between the two $R$. fascians strains and several lines of evidence support this hypothesis. Indeed, Cornelis et al. (2001) found that a lower proportion of BY-2 cells were infected by strain D188- 5 than by strain D188. Although both $R$. fascians strains colonize tobacco and Arabidopsis plant surfaces equally well, the efficiency of strain D188-5 to penetrate plant tissues was reported to be lower than that of strain D188 (Cornelis et al., 2001). In addition, both bacteria were shown to synthesize IAA, which was suggested to play a role in the colonization ability and in the growth and survival of $R$. fascians on its host plants, but IAA production was delayed in strain D188-5 (Vandeputte et al., 2005). Finally, although strain D188-5 does not induce the formation of leafy galls, it has been shown to affect plant development by partially blocking root growth of infected Arabidopsis plants (Crespi et al., 1992; Vereecke et al., 2000). These observations indicate that plants respond to both $R$. fascians strains, at least at the recognition level.

Further characterization of Ntann12 expression revealed that abiotic stresses also induced Ntann12 expression. Indeed, exposure of BY-2 cells to $\mathrm{NaCl}$ or ABA resulted in an increase of Ntann12 transcripts (Fig. 4). Expression of plant annexins, such as AnnMs2 from M. sativa and several annexins from $A$. thaliana, is known to be induced upon various environmental signals, including $\mathrm{ABA}$ and $\mathrm{NaCl}$ (Hoshino et al., 2004; Kovács et al., 1998; Lee et al., 2004; this study). Similarly to annexins of M. sativa (AnnMs2) (Kovács et al., 1998) and A. thaliana (AnnAt1) (Lee et al., 2004), Ntann12 was induced within $24 \mathrm{~h}$ after application of ABA or $\mathrm{NaCl}$. A role for annexins in the osmotic stress response is supported by the phenotype of AnnAt1 and AnnAt4 Arabidopsis T-DNA insertional mutants that were shown to be more sensitive to osmotic stress and ABA during germination and early seedling growth, as compared with wild-type plants (Lee et al., 2004).

Several plant annexins have been proposed to play a role during oxidative stress. Indeed, hydrogen peroxide $\left(\mathrm{H}_{2} \mathrm{O}_{2}\right)$ induces expression of annexins such as oxy5/Annat1 in Arabidopsis (Gidrol et al., 1996) and AnnMs2 in M. sativa (Kovács et al., 1998). In addition, heterologous expression of AnnAt1 has been shown to rescue E. coli $\triangle$ oxyR mutants from $\mathrm{H}_{2} \mathrm{O}_{2}$ stress (Gidrol et al., 1996) and to protect mammalian cells from $\mathrm{H}_{2} \mathrm{O}_{2}$-induced cell 
death (Kush and Sabapathy, 2001). Ntann12 was not induced by $\mathrm{H}_{2} \mathrm{O}_{2}$ treatment, suggesting that $\mathrm{Ntann} 12$ is not implied in an oxidative stress response.

Like other plant annexins (Cantero et al., 2006; Clark et al., 2001, 2005; de Carvalho-Niebel et al., 2002; Hoshino et al., 2004; Shin and Brown, 1999), Ntann12 expression is developmentally regulated (Fig. 6) but $R$. fascians infection results in an alternation of this expression. Ontogenesis of leafy gall involves a complex developmental alteration that begins with de novo cortical cell divisions at the sites of infection followed by the initiation and the formation of adventitious buds (de 0 . Manes et al., 2001). During the early differentiation steps of these shoot primordia, several genes have been shown to be expressed, among which are genes involved in the cell cycle machinery (de 0. Manes et al., 2001; Vereecke et al., 2000) and hormone homeostasis (Simón-Mateo et al., 2006). Ntann12 is also a gene whose expression is activated during leafy gall ontogenesis (Fig. 8) and at specific sites on tobacco leaves infected by $R$. fascians (Fig. 7). These specific infection sites probably correspond to actively dividing cells that will ultimately differentiate into the shoot primordia forming the leafy gall. The GUS staining pattern observed for Ntann12 (Fig. 7) is similar to that of B-type cyclin gene expression on infected tobacco plants by $R$. fascians (D188) (de O. Manes et al., 2001) and to the cytokinin oxidase gene expression following infection of pea plants with $R$. fascians (strain 602) (Gális et al., 2005).

In conclusion, plant annexins have been implicated in a variety of physiological processes, most of them dealing with stress response functions (Hofmann, 2004). NtAnn12 is indeed induced by various biotic and abiotic stresses and is also shown to be developmentally regulated. Annexins are proposed to be a link between $\mathrm{Ca}^{2+}$ signalling and membrane-related functions, such as membrane-cytoskeleton linkages, exocytic or endocytic processes and ion flux regulation (Gerke et al., 2005). According to Hofmann (2004), annexins act as parts of the complex signalling network that organize stresses and/or developmental processes rather than reacting themselves to these plant cell responses. Further functional characterization of this gene will certainly contribute to a better understanding of its role in plant development/physiology and of the events occurring at the interface between the cellular envelopes of both actors of the $R$. fascians-plant interaction.

\section{EXPERIMENTAL PROCEDURES}

\section{Plant material and growth conditions}

Non-transgenic and transgenic tobacco plants (Nicotiana tabacum cv. Havana) were grown aseptically on half-strength MS medium (Duchefa) supplemented with appropriate antibiotics when needed, or in a greenhouse at $25^{\circ} \mathrm{C}$ with a $16 / 8$-h light-dark photoperiod. Developing leafy galls used for RT-qPCR experiments were induced as described previously (de 0. Manes et al., 2001) on in vitro 4-week-old tobacco plants following spot-inoculation of axillary buds. Control plants were spot-inoculated with drops of the avirulent strain D188-5 (Crespi et al., 1992; Desomer et al., 1988) and non-infected plants (NIP) were mock-inoculated with drops of YEB medium. For RNA extraction, infected tissues were sampled at regular intervals and immediately frozen in liquid nitrogen.

\section{Infection of BY-2 cell suspensions by $\boldsymbol{R}$. fascians and other bacteria}

N. tabacum L. cv. Bright Yellow 2 (BY-2) cell suspension was cultivated and maintained in modified liquid Linsmaier and Skoog (LS) medium (Nagata et al., 1992) and incubated for 2 days in the dark at $28^{\circ} \mathrm{C}$ under shaking (130 r.p.m.) before infection. For the differential display, the virulent strain D188 of $R$. fascians was used. After 2 days incubation in liquid YEB medium $\left(\mathrm{OD}_{600 \mathrm{~nm}} \sim 2\right)$, $500 \mu \mathrm{L}$ of bacterial suspension was inoculated into $100 \mathrm{~mL}$ of BY2 cell suspension cultures. A YEB-inoculated cell suspension was used as control. Two days after bacterial inoculation, cell suspensions were filtered and frozen in liquid nitrogen. To confirm the differential expression by independent RT-PCR analysis, a similar procedure was performed using the virulent D188 or the avirulent D188-5 strain. For the expression analysis of Ntann12 in response to different bacteria, BY-2 cell suspensions were inoculated with R. fascians (strain D188), P. syringae pv. tabaci LMG 5393 (obtained from the Belgian Coordinated Collection of Microorganismshttp://bccm.belspo.be/about//mg.php), E. coli (strain DH5 $\alpha$ ) and A. tumefaciens (strain B6). In each case, bacteria were grown until an optical density at $600 \mathrm{~nm}$ of 2 was reached and $500 \mu \mathrm{L}$ of bacterial culture was added to 2-day-old BY-2 cell suspension cultures. BY-2 cells were harvested $0,24,48$ and $72 \mathrm{~h}$ after infection and frozen in liquid nitrogen.

\section{Abiotic stress treatments}

Two-day-old $\mathrm{BY}$-2 cell suspension cultures were treated with $\mathrm{NaCl}(150 \mathrm{~mm}), \mathrm{ABA}(150 \mu \mathrm{m})$ or $\mathrm{H}_{2} \mathrm{O}_{2}(50 \mathrm{~mm})$. BY-2 cells were harvested 0, 2, 4, 8 and $24 \mathrm{~h}$ after treatment and frozen in liquid nitrogen.

\section{RNA extraction and mRNA differential display}

Total RNA was extracted from BY-2 cell suspension and from various tissues of tobacco plants using the RNeasy ${ }^{\circledR}$ Plant Mini Kit (Qiagen, Hilden, Germany) according to the manufacturer's instructions. Reverse transcription of mRNA was performed using A, B, C and D RNAmap ${ }^{\text {TM }}$ kits from GenHunter (Nashville, TN). In this work, the T12MG (where $M=A, G, C$ ) oligo-dT primer mix was used in combination with the 20 arbitrary primers (AP 1-20) 
(GenHunter). Separation of CDNA fragments was made on 5\% polyacrylamide denaturing gels and revealed by autoradiography. cDNA fragments were cut off from the gels, reamplified by the original primer combination, cloned in the $\mathrm{PC}{ }^{\circledR} 4-\mathrm{TOPO}^{\circledR}$ vector (Invitrogen) and sequenced.

\section{Cloning of the Ntann12 cDNA from BY2 cells and from tobacco plants}

A 5'RACE system for rapid amplification of CDNA ends (Gibco BRL, MD) was used to amplify the 5' part of the Ntann12 CDNA on CDNA made from $R$. fascians-infected BY-2 cell suspension. The primers used were the forward (F) Poly G 5'-GGCCACGCGTCGACTAGTACGGGGGGGGGGGGGGGG-3' furnished in the kit and the reverse (R) gene-specific primers $5^{\prime}$-CTTCTCTGCCCTTGTAACTAT- $3^{\prime}$ and 5'-TTGTAGTAAAGCTCCT TGATA- $3^{\prime}$. The amplified CDNA fragment was cloned in the $\mathrm{PCR} 4{ }^{\circledR}-\mathrm{TOPO}^{\circledR}$ vector and sequenced. Subsequently, the entire length of the CDNA obtained for Ntann 12 was amplified using the primers $F 5^{\prime}$-GAGAAGAAATTAAATCCATTGATTAGG-3' and R 5'-CGACGGAAAAGAATATTGATAGC $-5^{\prime}$ on CDNA obtained from BY-2 or from N. tabacum plantlets cultured in vitro. Both CDNAs were subsequently cloned in a $\mathrm{PCR} 4^{\circledR}-\mathrm{TOPO}^{\circledR}$ vector and sequenced. Protein sequences were aligned with CLUSTAL W (http://www.ebi.ac.uk/clustalw) (Thompson et al., 1994), and page set-up was made with BOXSHADE (http://www.ch.embnet.org/software/BOX_form.html). Molecular weight was calculated with the software PEPSTATS (http://bioweb.pasteur.fr/seqanal/interfaces/pepstats.html).

\section{RT-PCR analysis and real-time quantitative RT-PCR (RT-qPCR)}

RT-PCR was performed using a reverse transcription system from Promega with primers amplifying 946 bp of the coding sequence of Ntann12, F 5'-ATGGCTACAATCAATTACCCT-3' and R 5'-CATTTCCCAAAAGAGCGAGA- $3^{\prime}$. EF1- $\alpha$ was amplified with primers $F$ $5^{\prime}$-TGCTACCACCCCCAAGTACTC- $3^{\prime}$ and R $5^{\prime}$-TAAAGCTGGCAGCACCCTTAG- $3^{\prime}$ and 185 was amplified with primers $F 5^{\prime}$-ATGGCCGTTCTTAGTTGGTG- $3^{\prime}$ and R $5^{\prime}$-TGTCGGCCAAGGCTATAAAC- $3^{\prime}$. RT-qPCR reactions were performed with primers $F 5^{\prime}$-CTTCTCTGCCCTTGTAACTAT-3' and R 5'-CAACCGCTACAAGGGTGATTA-3'. Conditions for RT-qPCR were as follows: 2 min at $50{ }^{\circ} \mathrm{C}, 10 \mathrm{~min}$ at $95^{\circ} \mathrm{C}, 40$ cycles of $30 \mathrm{~s}$ at $95^{\circ} \mathrm{C}, 1 \mathrm{~min}$ at $60^{\circ} \mathrm{C}$ and $1 \mathrm{~min}$ at $72^{\circ} \mathrm{C}$. As a final step, a dissociation curve consisting of $15 \mathrm{~s}$ denaturation at $95^{\circ} \mathrm{C}, 15 \mathrm{~s}$ at $60^{\circ} \mathrm{C}$ and $15 \mathrm{~s}$ at $95^{\circ} \mathrm{C}$ was performed to detect unwanted primer-dimers or PCR products that could interfere with the fluorescence data. Reactions were composed of $12.5 \mu \mathrm{L}$ iTaq SYBR Green (Bio-Rad), $9.5 \mu \mathrm{L}$ water, $2 \mu \mathrm{L}$ primer mix (5 $\mu \mathrm{m}$ each) and $1 \mu \mathrm{L}$ of CDNA (diluted four-fold). qPCRs were performed in an ABI 7900 system (Applied Biosystems). Expression of the EF1- $\alpha$ gene was used to normalize the samples. qPCR data were analysed by the $\Delta \Delta C_{T}$ method as described by Livak and Schmittgen (2001) and are reported as ratios between expression in plants infected with strains D188-5 or D188 vs. non-infected plants (NIP). To test whether Ntann12 was expressed at a higher level following infection of plants by $R$. fascians and to test whether there was a difference of expression between D188-5- and D188-infected plants (the null hypothesis being that the expression of Ntann12 was not altered in the different conditions), $t$-tests were conducted and a $P$-value was calculated and used to reject the null hypothesis. A $P$-value $\leq 0.01$ was considered as being significant.

\section{Amplification of the promoter region of Ntann12, construction of Ntann12 promoter-GUS constructs and plant transformation}

Genomic DNA was extracted from N. tabacum aerial parts using a DNeasy plant Mini kit (Qiagen). The Universal Genome Walker ${ }^{\mathrm{TM}}$ kit (Clontech) was used according to the manufacturer's instruction and allowed to amplify a 542-bp DNA fragment that was cloned in the $\mathrm{PCR} 4^{\circledR}-\mathrm{TOPO}^{\circledR}$ vector (Invitrogen) and sequenced. This fragment was flanked by attB1 and attB2 recombination sites by two PCR reactions. For the first PCR reaction primers $F 5^{\prime}$ AAAAAGCAGGCTAAATACTCGGCGGTG-3' and R 5'-AGAAAGCTGGGTCGTTAAACTCTCTTCC- $3^{\prime}$ were used. A second PCR with primers $F 5^{\prime}$-GGGGACAAGTTTGTACAAAAAAGCAGGCT- $3^{\prime}$ and $R$ 5'-GGGGACCCTTTGTACAAGAAAGCTGGGT-3' was performed, creating the entire attB1 and attB2 recombination sites (1 min at $94{ }^{\circ} \mathrm{C}, 1 \mathrm{~min}$ at $60^{\circ} \mathrm{C}, 30$ cycles of $1.5 \mathrm{~min}$ at $68^{\circ} \mathrm{C}$ followed by 10 min at $68^{\circ} \mathrm{C}$ ). PCR reactions were performed using the Platinum Pfx Polymerase (Invitrogen). This PCR fragment was cloned into the Gateway ${ }^{\mathrm{TM}}$-compatible binary T-DNA destination vector pKGWFS7, allowing the fusion of Ntann12 promoter with both GFP and GUS reporter genes (Karimi et al., 2002) in reactions mediated by the Gateway ${ }^{\mathrm{TM}}$ BP and LR Clonase ${ }^{\mathrm{TM}}$ Enzyme Mix (Invitrogen). This plasmid was transferred into A. tumefaciens strain C58Rif ${ }^{R}$ (pGV2260). N. tabacum was transformed by the leaf disc protocol according to Deblaere et al. (1987) with slight modifications. Thidiazuron (1 mg/L) was used instead of benzylaminopurine. Transgenic plants were selected on half-strength MS medium (Duchefa) supplemented with $200 \mathrm{mg} / \mathrm{L}$ kanamycin at $25^{\circ} \mathrm{C}$ under a 16 -h/8-h light-dark photoperiod. T-DNA insertions were verified by PCR analysis and homozygous seedlings (T2) were used for histochemical GUS staining, which was performed as described by Hemerly et al. (1993).

\section{Generation of EGFP fusion constructs and transformation of BY-2 cells}

Gateway ${ }^{\mathrm{TM}}$ (Invitrogen) attB1 and attB2 sequence extensions were added for in-frame cloning into plant Gateway destination 
vectors pK7WGF2, pK7WGF2 or pK7FWGF2 (Karimi et al., 2002) to generate $\mathrm{N}$-terminal, $\mathrm{C}$-terminal or both $\mathrm{N}$ - and $\mathrm{C}$-terminal EGFP-Ntann12 fusion products downstream of the CaMV35S promoter. Plasmids were transferred to A. tumefaciens strain LBA4404. Stable BY-2 transformation was carried out as described (Geelen and Inzé, 2001). Approximately ten transgenic BY-2 calli of $1 \mu \mathrm{m}$ diameter were examined for fluorescence under a coverslip with an Axioskop (Zeiss) fluorescence microscope. EGFP-positive calli were analysed by confocal microscopy (Zeiss 100M, equipped with LSM510 software version 3.2). A 63x water-corrected objective (numerical aperture of 1.2) was used to scan the samples. The images were captured with the LSM510 image acquisition software (Zeiss).

\section{Nucleotide sequence accession numbers}

Sequences of Ntann12 isolated from tobacco and BY-2 cDNAs are deposited in the GenBank nucleotide sequence database under accession numbers AY965682 and AY965683, respectively. The sequence of the Ntann12 promoter is deposited in the GenBank nucleotide sequence database under accession number DQ900657.

\section{ACKNOWLEDGEMENTS}

We acknowledge Koen Goethals and Danny Vereecke for providing the BY-2 cell suspension and $R$. fascians strains. Students Glenda Willems, Annabelle Calomme, Jean-Philippe Vandenauwe, Bertrand Chanson and Laurent Grumiaux are acknowledged for their contribution. M.B. is a Research Associate of the National Fund for Scientific Research (Belgium).

\section{REFERENCES}

Anzai, H., Yoneyama, K. and Yamaguchi, I. (1989) Transgenic tobacco resistant to a bacterial disease by the detoxification of a pathogenic toxin. Mol. Gen. Genet. 219, 492-494.

Breton, G., Vazquez-Tello, A., Danyluk, J. and Sarhan, F. (2000) Two novel intrinsic annexins accumulate in wheat membranes in response to low temperature. Plant Cell Physiol. 41, 177-184.

Cantero, A., Barthakur, S., Bushart, T.J., Chou, S., Morgan, R.O., Fernandez, M.P., Clark, G.B. and Roux, S.J. (2006) Expression profiling of the Arabidopsis annexin gene family during germination, de-etiolation and abiotic stress. Plant Physiol. Biochem. 44, 13-24.

Carroll, A., Moyen, C., Van Kesteren, P., Tooke, F., Battey, N.H. and Brownlee, C. (1998) $\mathrm{Ca}^{2+}$, annexins, and GTP modulate exocitosis from maize root cap protoplasts. Plant Cell, 10, 1267-1276.

de Carvalho Niebel, F., Lescure, N., Cullimore, J.V. and Gamas, P. (1998) The Medicago truncatula Mtann1 gene encoding an annexin is induced by Nod factors and during the symbiotic interaction with Rhizobium meliloti. Mol. Plant-Microbe Interact. 11, 504-513.

de Carvalho-Niebel, F., Timmers, A.C.J., Chabaud, M., Defaux-Petras, A. and Barker, D.G. (2002) The Nod factor-elicited annexin MtAnn1 is preferentially localised at the nuclear periphery in symbiotically activated root tissues of Medicago truncatula. Plant J. 32, 343-352.

Clark, G.B., Dauwalder, M. and Roux, S.J. (1992) Purification and immunolocalization of an annexin-like protein in pea seedlings. Planta, 187, 1-9.

Clark, G.B., Lee, D., Dauwalder, M. and Roux, S.J. (2005) Immunolocalization and histochemical evidence for the association of two different Arabidopsis annexins with secretion during early seedling growth and development. Planta, 220, 621-631.

Clark, G.B., Rafati, D.S., Bolton, R.J., Dauwalder, M. and Roux, S.J. (2000) Redistribution of annexin in gravistimulated pea plumules. Plant Physiol. Biochem. 38, 937-947.

Clark, G.B., Sessions, A., Eastburn, D.J. and Roux, S.J. (2001) Differential expression of members of the annexin multigene family in Arabidopsis. Plant Physiol. 126, 1072-1084.

Cornelis, K., Ritsema, T., Nijsse, J., Holsters, M., Goethals, K. and Jaziri, M. (2001) The plant pathogen Rhodococcus fascians colonizes the exterior and interior of the aerial parts of the plants. Mol. Plant-Microbe Interact. 14, 599-608.

Crespi, M., Messens, E., Caplan, A.B., Van Montagu, M. and Desomer, J. (1992) Fasciation induction by the phytopathogen Rhodococcus fascians depends upon a linear plasmid encoding a cytokinin synthase gene. EMBO J. 11, 795-804.

Crespi, M., Vereecke, D., Temmerman, W., Van Montagu, M. and Desomer, J. (1994) The fas operon of Rhodococcus fascians encodes new genes required for efficient fasciation of host plants. J. Bacteriol. 176, 2492-2501.

Deblaere, R., Reynaerts, A., Höfte, H., Hernalsteens, J.-P., Leemans, J. and Van Montagu, M. (1987) Vectors for cloning in plant cells. Meth. Enzymol. 153, 277-292.

Delmer, D.P. and Potikha, T.S. (1997) Structures and functions of annexins in plants. Cell. Mol. Life Sci. 53, 546-553.

Desomer, J., Dhaese, P. and Van Montagu, M. (1988) Conjugative transfer of cadmium resistance plasmids in Rhodococcus fascians strains. J. Bacteriol. 170, 2401-2405.

Ditt, R.F., Kerr, K.F., de Figueiredo, P., Delrow, J., Comai, L. and Nester, E.W. (2006) The Arabidopsis thaliana transcriptome in response to Agrobacterium tumefaciens. Mol. Plant-Microbe Interact. 19, 665-681.

Eason, J.R., Morris, R.O. and Jameson, P.E. (1996) The relationship between virulence and cytokinin production by Rhodococcus fascians (Tilford 1936) Goodfellow 1984. Plant Pathol. 45, 323-331.

Gális, I., Bilyeu, K.D., Godinho, M.J.G. and Jameson, P.E. (2005) Expression of three Arabidopsis cytokinin oxidase/dehydrogenase promoter: GUS chimeric constructs in tobacco: response to developmental and biotic factors. Plant Growth Regul. 45, 173-182.

Geelen, D.N.V. and Inzé, D.G. (2001) A bright future for the Bright Yellow2 cell culture. Plant Physiol. 127, 1375-1379.

Gerke, V., Creutz, C.E. and Moss, S.E. (2005) Annexins: linking Ca ${ }^{2+}$ signalling to membrane dynamics. Nature Rev. Mol. Cell Biol. 6, 449-461.

Gidrol, X., Sabelli, P.A., Fern, Y.S. and Kush, A.K. (1996) Annexin-like protein from Arabidopsis thaliana rescues $\triangle$ oxy $R$ mutant of Escherichia coli from $\mathrm{H}_{2} \mathrm{O}_{2}$ stress. Proc. Natl Acad. Sci. USA, 93, 11268-11273.

Goethals, K., Vereecke, D., Jaziri, M., Van Montagu, M. and Holsters, M. (2001) Leafy gall formation by Rhodococcus fascians. Annu. Rev. Phytopathol. 39, 27-52.

Hemerly, A.S., Ferreira, P., de Almeida Engler, J., Van Montagu, M., Engler, G. and Inzé, D. (1993) cdc2a expression in Arabidopsis is linked with competence for cell division. Plant Cell, 5, 1711-1723. 
Hofmann, A. (2004) Annexins in the plant kingdom: perspectives and potentials. Annexins, 1, 51-61.

Hoshino, D., Hayashi, A., Temmei, Y., Kanzawa, N. and Tsuchiya, T. (2004) Biochemical and immunohistochemical characterization of Mimosa annexin. Planta, 219, 867-875.

Karimi, M., Inzé, D. and Depicker, A. (2002) GATEWAYTM vectors for Agrobacterium-mediated plant transformation. Trends Plant Sci. 7, 193195.

Kovács, I., Ayaydin, F., Oberschall, A., Ipacs, I., Bottka, S., Pongor, S., Dudits, D. and Tóth, É.C. (1998) Immunolocalization of a novel annexin-like protein encoded by a stress and abscisic acid responsive gene in alfalfa. Plant J. 15, 185-197.

Kush, A. and Sabapathy, K. (2001) 0xy5, a novel protein from Arabidopsis thaliana, protects mammalian cells from oxidative stress. Int. J. Biochem. Cell Biol. 33, 591-602.

Lee, S., Lee, E.J., Yang, E.J., Lee, J.E., Park, A.R., Song, W.H. and Park, O.K. (2004) Proteomic identification of annexins, calcium-dependent membrane binding proteins that mediate osmotic stress and abscisic acid signal transduction in Arabidopsis. Plant Cell, 16, 1378-1391.

Livak, K.J. and Schmittgen, T.D. (2001) Analysis of relative gene expression data using real-time quantitative PCR and the $-2^{\Delta \Delta C}$ method. Methods, 25, 402-408.

Manthey, K., Krajinski, F., Hohnjec, N., Firnhaber, C., Pühler, A., Perlick, A.M. and Küster, H. (2004) Transcriptome profiling in root nodules and arbuscular mycorrhiza identifies a collection of novel genes induced during Medicago truncatula root endosymbioses. Mol. Plant-Microbe Interact. 17, 1063-1077.

Moss, S.E. and Morgan, R.O. (2004) The annexins. Genome Biol. 5, 219.

Nagata, T., Nemoto, Y. and Hasezawa, S. (1992) Tobacco BY-2 cell line as the 'HeLa' cell in the cell biology of higher plants. Int. Rev. Cytol. 132, $1-30$.

Nouar, E.H., Vereecke, D., Goethals, K., Jaziri, M. and Baucher, M. (2003) Screening for differential gene expression in Atropa belladonna leafy gall induced following Rhodococcus fascians infection. Eur. J. Plant Pathol. 109, 327-330. de O. Manes, C.-L., Van Montagu, M., Prinsen, E., Goethals, K. and Holsters, M. (2001) De novo cortical cell division triggered by the phytopathogen Rhodococcus fascians in tobacco. Mol. Plant-Microbe Interact. 14, 189-195.

Okamoto, T., Higuchi, K., Shinkawa, T., Isobe, T., Lörz, H., Koshiba, T. and Kranz, E. (2004) Identification of major proteins in maize egg cells. Plant Cell Physiol. 45, 1406-1412.

Shin, H. and Brown, R.M. Jr (1999) GTPase activity and biochemical characterization of a recombinant cotton fiber annexin. Plant Physiol. 119, 925-934.

Simón-Mateo, C., Depuydt, S., De Oliveira Manes, C.L., Cnudde, F., Holsters, M., Goethals, K. and Vereecke, D. (2006) The phytopathogen Rhodococcus fascians breaks apical dominance and activates axillary meristems by inducing plant genes involved in hormone metabolism. Mol. Plant Pathol. 7, 103-112.

Thompson, J.D., Higgins, D.G. and Gibson, T.J. (1994) CLUSTAL W: improving the sensitivity of progressive multiple sequence alignment through sequence weighting, positions-specific gap penalties and weight matrix choice. Nucleic Acids Res. 22, 4673-4680.

Thonat, C., Mathieu, C., Crevecoeur, M., Penel, C., Gaspar, T. and Boyer, N. (1997) Effects of a mechanical stimulation on localization of annexin-like proteins in Bryonia dioica internodes. Plant Physiol. 114, 981-988.

Vandeputte, O., Öden, S., Mol, A., Vereecke, D., Goethals, K., El Jaziri, M. and Prinsen, E. (2005) Biosynthesis of auxin by the Gram-positive phytopathogen Rhodococcus fascians is controlled by compounds specific to infected plant tissues. Appl. Environ. Microbiol. 71, 11691177.

Vereecke, D., Burssens, S., Simón-Mateo, C., Inzé, D., Van Montagu, M., Goethals, K. and Jaziri, M. (2000) The Rhodococcus fascians-plant interaction: morphological traits and biotechnological applications. Planta, 210, 241-251.

Vereecke, D., Messens, E., Klarskov, K., De Bruyn, A., Van Montagu, M. and Goethals, K. (1997) Patterns of phenolic compounds in leafy galls of tobacco. Planta, 201, 342-348. 